\title{
The Role and Logic of Nontraditional Security in China's Engagement in Global Governance Mechanisms under Xi Jinping's Regime
}

\author{
Liu Hongyi ${ }^{1,2}$ (D)
}

Accepted: 12 October 2020/Published online: 20 October 2020

(C) Journal of Chinese Political Science/Association of Chinese Political Studies 2020

\begin{abstract}
With the emergence of a series of global security incidents, scholars and observers have placed increasing importance on nontraditional security (NTS). Since 2012, Xi Jinping's regime has emphasized NTS issues and cooperation, which begs the question "What is the role of NTS in China's foreign policy, and how is it shaped?" This study analyzes articles that include the term “nontraditional security” (“非传统安全”) in The People's Daily newspaper since its first mention in 2001. Focusing particularly on the period between 2012 and 2019, the study explains China's securitization process and its motivations toward NTS issues. By analyzing case studies of the NTS issues of terrorism, environmental issues, and cybersecurity, and further summarizing the logic in common behind the Chinese government's process of securitizing NTS issues, this paper highlights the correlation between the characteristics of China's NTS and China's major foreign policy initiatives that play an active role in leading international efforts to enhance global governance and exploring new models of cooperation. Based on an analysis of China's emphasis on promotion of NTS and provision of public goods, I argue that NTS has played an increasingly important role in China's pursuit of greater influence in global governance mechanisms.
\end{abstract}

Keywords China $\cdot$ Nontraditional security $\cdot$ Foreign policy $\cdot$ Global governance $\cdot$ People's daily

Liu Hongyi

chrisliu8023@126.com

1 Graduate School of Social Science, Waseda University, Tokyo, Japan

2 Shanghai, China 


\section{Introduction}

With the emergence of a series of global security incidents, including terrorist attacks, natural disasters, and infectious diseases, etc., nontraditional security (NTS) has been increasingly discussed by scholars and observers. As an emerging world power, China's participation in NTS areas is indispensable in global governance mechanisms. China's response to the major NTS crisis such as the COVID-19 pandemic at the end of 2019 called for a focus on the relation between China's NTS and its foreign policy.

Although China has tried to expand its role in nonmilitary security and global governance, most scholarly studies of China's military activities and the relationship between it and neighboring countries still focus on traditional security. There is no doubt that China's rise has brought about increasing concerns over its expansion of military power and its assertive diplomacy. The rivalry between China and the United States has been the primary focus of previous literature, but overanalyzing China's military actions and motives as related to diplomacy from the perspective of traditional military security entails risks. On the one hand, it could lead to an inaccurate estimation of China's intentions; on the other hand, it could waste opportunities for cooperation. However, despite the limited discussion of China's NTS policies in the literature, it is undeniable that NTS has gained greater significance in China's policymaking since the introduction of the "new security concept" in the 1990s along with the first official mention of the NTS concept in 2001.

China's mention of NTS in official media increased significantly in the early $2000 \mathrm{~s}$, from 11 articles in The People's Daily newspaper in 2001, to 78 in 2005, and 66 in 2007. After a lull between 2008 and 2009, mentions notably increased from 2010, with The People's Daily mentioning the term in 68 articles in 2010, 82 in 2014, and 87 in 2015 (Fig. 1).

On January 9, 2017, Joseph S. Nye, a renowned scholar of international relations, warned of the dangers of the so-called "Kindleberger Trap" in which China free rides rather than contributing to global governance and is too weak to provide global public goods in the context of its rapid growth [20]. In fact, since the 2000s, there has been ongoing debate on whether China has the capability and intention to play the role of a

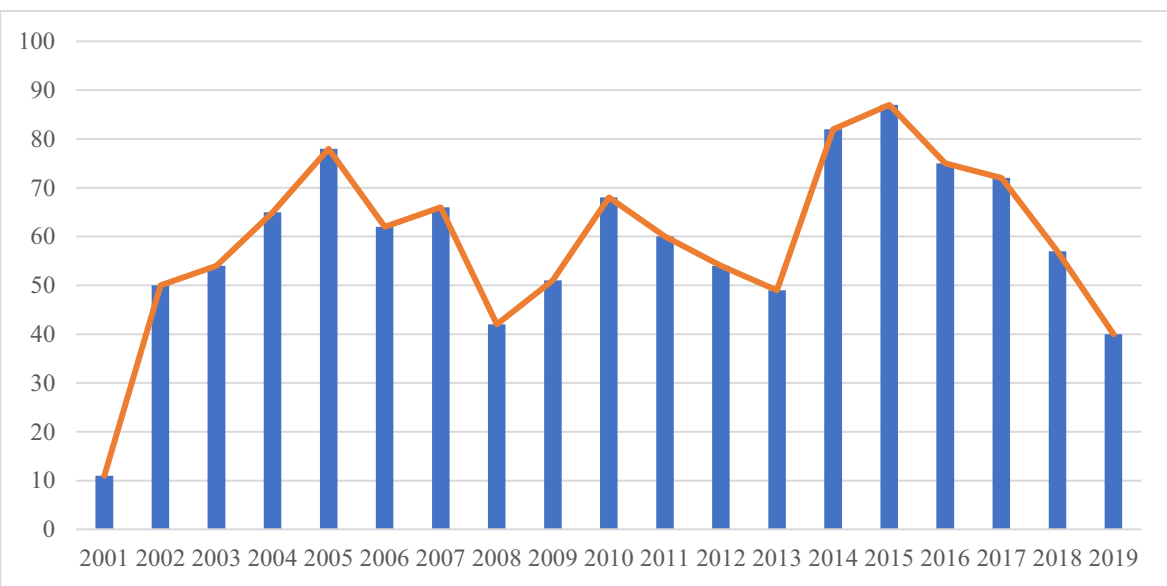

Fig. 1 Number of articles featuring “nontraditional security” (“非传统安全”) in People’s Daily 
great power in global governance and provide global public goods. There is growing concern as to whether China will take responsibility in the existing international order, especially after rejecting the judgement of the Permanent Court of Arbitration concerning the rights of the Philippines in the South China Sea. At the same time, China has attempted to dispel those concerns by actively participating in global governance and international cooperation.

Under Xi Jinping's regime, via a series of iconic policies and guidance, such as "community of a shared future for mankind" and the Belt and Road Initiative, China has shown its determination to play a more active role in leading international efforts to enhance global governance and explore new models of cooperation ([10], p. 1, [46], pp. 23-24). Affected by this trend, recent studies are increasingly linking these initiatives to China's foreign policy shift (see, for instance, [9, 22, 28]). As an indispensable part of global governance, it is necessary to assess the role that NTS plays in such a major foreign policy shift by China. Therefore, this paper attempts to investigate the following questions: To what extent does NTS have an impact on China's foreign policy under Xi Jinping's regime? What role has it played in China's expanding influence in international affairs during this period? In particular, to what extent, does NTS play a role in China's pursuit of greater influence in global governance mechanisms? To answer these questions, the paper focuses on China's securitization process as it relates to NTS issues within those fields increasingly emphasized by the Chinese government under Xi's regime. By analyzing speeches and articles containing statements by Chinese government officials and explaining the growing role that NTS plays in China's foreign policy, this paper provides a better understanding of China's motivations toward both NTS policy and international cooperation.

\section{Literature Review}

Regarding the definition of nontraditional security, although global issues such as terrorism, climate change and infectious diseases are often taken as the object of security research, the previous literature does not offer a specific definition by which to categorize issues that are NTS-related and those that are not. Regarding NTS, the only generally accepted definition is that it has nonmilitary characteristics. Yu Xiaofeng and Wang Jiangli ([39], p. 57) asserted that NTS concerns nonmilitary security issues, marking the "transformation from sovereignty threats into survival threats" and the "transformation from military security and political security to all areas related to national security, human security and social security." Moreover, Mely CaballeroAnthony ([7], p. 6) concluded that the recognition of NTS issues shifts the focus of security away from state-centrism and traditional military and territorial security. Shi Bin ([31], p. 97) believes that since the 1990s, with the expansion of nonmilitary threats, the understanding of security has moved from being state-centric to being people- and world-centric. Considering that China has defined at least 20 different NTS areas in government speeches in the past 20 years, this paper uses NTS in the sense of security in nonmilitary areas.

In contemporary studies of Chinese diplomacy, research methods from multiple perspectives has been examined and adopted. Young Chul Cho \& Yih-Jye Hwang ([38]: 175) criticized the mainstream international relations approaches (realism, 
liberalism, and constructivism) that serve the US/Western hegemony for not providing value-free explanations when analyzing China's rise. In addition, Cai Kevin G. ([8], p. 355) warned that excessive emphasis on the role of traditional security may be accompanied by risks. Thus, although the role of NTS in China's foreign policy is still considered limited in comparison with traditional security matters and issues of regional competition, a large number of studies have been focusing on the role of NTS in China's diplomacy from multiple perspectives. In considering how China's concept of NTS influences its diplomacy, Ali Abdullah Wibisono [36] summarized the characteristics and achievements of NTS cooperation between China and the Association of Southeast Asian Nations (ASEAN), and asserted the need for collaboration on NTS between China and ASEAN. According to Wibisono, both China and ASEAN are involved in such cooperation in a way that is consistent with the political goals of China as well as the ASEAN members. In this context, China's goal is to expand its influence in the ASEAN region and to address NTS threats through increasing economic exchanges. However, under Xi Jinping's regime, China expanded the region of NTS cooperation under the guidance of the Belt and Road initiative and the "community of a shared future for mankind" and showed an intention to contribute to the global governance system. Therefore, in addition to China's relationship with ASEAN, it is necessary to examine other motivations of China's NTS cooperation.

Andrea Ghiselli [11] systematically analyzed the correlation between various external threats and particularly focused on the risks to the lives and safety of citizens and the growing role of NTS in China's foreign policy. Ghiselli conclude that the expansion of China's overseas interests, the security of its citizens, and the increase in overseas missions of the People's Liberty Army (PLA) have played significant role in China's foreign policy. However, the background of China's increasing international responsibility should not be neglected. Ghiselli's research, for example, pays little attention to the significance of China's Belt and Road Initiative and the "community of a shared future for mankind." While he emphasized the safety of citizens and national security, he overlooked China's motivation to assume greater international responsibility and provide public goods through NTS cooperation in fields such as natural disasters, cybersecurity and climate change. Regarding China's policymaking, Ghiselli focused on China's guiding opinions such as the National Security Law promulgated in July 2015 and the new Anti-Terrorism Law promulgated in December of that same year. However, among all the security issues covered by the National Security Law, cybersecurity, natural disasters, and environmental security which have been gradually inserted into China's security agenda have not been adequately analyzed. The correlation between China's willingness to play a role in global governance and the concept of NTS also requires more attention.

Jeffrey Reeves [30] postulated that the structural weakness of the states on China's borders led to China's awareness and expansion of NTS. He focused on how the weakness of these neighboring countries has an impact on China's security policy. According to Reeves, this external environment makes China more vulnerable to nontraditional threats such as terrorism, energy security, and environmental security. However, the domestic security environment alone cannot explain China's deepening NTS cooperation with countries other than 
its neighbors. Therefore, it is still necessary to link China's attention to NTS issues with China's foreign policy.

Masuda Masayuki [27] discussed China's NTS cooperation from two perspectives. First, the involvement of the PLA in regional NTS cooperation has led to the PLA having the new task of engaging in "diplomacy." Second, regarding regional NTS cooperation, China has tried to enhance the PLA's capability to carry out crisis management. Masuda believed that the expansion of NTS cooperation resulted in the PLA being assigned additional tasks and strengthened China's military involvement in event requiring regional cooperation. As Masuda emphasized, it is undeniable that in many NTS fields, the PLA's involvement is indispensable. However, although he tried to argue from the perspective of the PLA, it cannot be disregarded that China also promoted cooperation in fields not directly related to the PLA such as climate changes and cybersecurity. Thus, the PLA's active role can be considered a result of China's expansion of the definition of NTS rather than the cause.

To explain the process by which China incorporates NTS issues into its policies in the context of changes in the internal and external environments, this paper examines China's security concept using securitization theory what is often referred to as the "Copenhagen School". A typical argument of securitization theory holds that it is necessary to develop a holistic security concept that provides a framework that can serve those who wish to apply this concept to specific cases without attempting to give a precise and widely accepted definition of security ([5], p. 11, [17], p. 482). Owing to its open definition of security, securitization theory opened up new horizons to NTS research. As scholars of the Copenhagen School posited, when an issue is expressed as a threat to a specific object, it is a security issue ([6], p. 21, [35], p. 369). Moreover, Ole Wæver ([34], pp. 51-52) also explained the process of securitization as a speech act, stating that "a problem would become a security issue whenever so defined by the power holders". Along these lines, official speeches by government officials can accordingly reflect the securitization trend in the country's security policies. Moreover, according to securitization theory, the purpose of this field is to gain an increasingly precise understanding of who can securitize, which issues (threats) exist, for whom (referent objects), why, with what kinds of effects, and under which conditions, which collectively explain when securitization has been successful ([6], p. 32). Therefore, this paper will discuss the securitizing actor and the empowering audience in China's process of securitizing NTS issues accordingly.

Although the practice of securitization is mainly concentrated in European democratic countries, all types of political systems are considered as applicable for analysis within the framework. Juha A. Vuori [33] proved that securitization theory is applicable to a non-democratic country like China by using this theory to explain China's illocutionary logic in a series of official speeches. However, securitization theory can also have some limitations in the Chinese environment. For example, Yu Xiaofeng and Xie Guiping ([40], pp. 108-110) stated that the lack of an explanation of how specific issues are selected as relating to security in securitization theory may lead to the following three dilemmas: (1) the excessive exaggeration of threats or insufficient desecuritization in the process of turning public issues into security issues; (2) the undervaluing or ignoring of security issues that actually exist; and (3) the attempt to establish enemies that do not exist in the process of securitization. Similar to Yu and Xie's opinion, Liu Qingyao asserted that although securitization theory provides a new 
perspective for studying NTS, further explanation is required to demonstrate why actors select and securitize specific issues in the process of the formation of NTS ([25], pp. 131-132). It can be concluded that when studying China's securitization in the field of NTS, it is necessary to examine the country's selection of security issues. Pinpointing only specific NTS issues and ignoring the shifting selection of all NTS issues can lead to an incomplete and biased analysis. Therefore, this paper attempts to focus on the frequency with which different NTS fields receive attention in China's securitization agenda and to further summarize the commonalities in these areas.

As scholars of the Copenhagen School proposed, the focus of securitization is "speech act" that constitutes particular security issue ([13], p. 359). Additionally, Zhu Ning affirmed the positive role of the securitization process in strengthening social integration and social identification ([47], p. 26). Yet, at the same time, it can also be observed that scholars rarely use Chinese official media reports and comments on NTS as research materials. To examine China's motivation for inserting more NTS issues into its security agenda, this paper concentrates on discourses highly correlated to Chinese NTS propaganda in official speeches.

Analyzing the context of Chinese newspapers, especially those owned and operated by the Chinese government (e.g., The People's Daily, Global Times, China Daily), as sources through which to interpret the Chinese government's attitude has been regarded as a common method in contemporary Chinese studies. As the mouthpiece of the Chinese Communist Party, The People's Daily claims to "have actively propagated the ideology of the Chinese Communist Party in the last 70 years." "In Chinese studies, the advantages of analyzing the content of Chinese state-owned media can be summarized as follows: "[By] operating at a national level, state-owned media are often perceived to represent the voices of the state, its leaders, or the Chinese Communist Party. This has the added advantage for scholarly work to understand and analyze the official narratives behind the pronouncements and ideological inclinations of the Party" ([24], p. 201). Therefore, the advertisements of The People's Daily can be considered as speech acts of the Chinese government and the change in the frequency of specific words and phrases that appear in these newspapers can also indicate trends within Chinese policies. For example, Michael D. Swaine examined China's diplomatic behavior by focusing on the term "core interest" as used by the Chinese government in this publication. He counted the frequency of this expression and analyzed the content of the articles in which it appeared. Based on this analysis, Swaine also categorized the definition of, and discourse related to "core interest" in The People's Daily and further explained the features that drive China's foreign policy [32]. Similarly, the present paper focuses on the illocutionary logic of The People's Daily and the frequency of "NTS" within its pages between 2001 and 2019, and specifically focus on $\mathrm{Xi}$ Jinping's regime, in order to interpret the motivation that drives China's securitization in NTS fields.

\footnotetext{
${ }^{1}$ Introduction to The People's Daily. Available online, http://www.people.com.cn/GB/50142/104580/index. html (accessed July 5, 2020).
} 


\section{References to the NTS Issue in The People's Daily}

As discussed above, the shift in references to NTS in official speeches in China can mark a change in emphasis in the country's securitization actions. For example, natural disasters and infectious diseases were not regarded as NTS issues until 2003 and 2005, respectively. However, triggered by the SARS crisis and the 2004 Sumatra-Andaman earthquake, China's definition of NTS in official speeches was expanded to include these new threats. The change in emphasis on security issues not only indicates China's cooperative attitude but also reflects its securitization process regarding these NTS fields.

In the first stage of analysis in this study, the Chinese version of The People's Daily online archive was used to collect all the articles that contained the term "nontraditional security”(“非传统安全”) at least once in the text and/or title and were published between July 2001 (when NTS was mentioned in The People's Daily for the first time) and December 2019. Keyword searches were conducted using simplified Chinese. A sample of 1123 articles was collected that spanned this period. In this study, through Python-based programming, all sentences containing the term "nontraditional security" were extracted. Then, the frequency of the mentions of specific NTS issues within these sentences was counted. Given that Chinese government officials have mentioned more than 30 different NTS fields in speeches in the past 20 years, this study only counted non-military security fields that were defined as NTS issues at least twice in The People's Daily. ${ }^{2}$ After removing the issues wherein the key term was mentioned less than twice and after further categorizing the same areas, China's NTS issues were classified into 17 fields as shown in Table 1.

\section{Results}

Although China's first official mention of NTS was made at the ASEAN Regional Forum (ARF) in July 2001, many scholars believe that the transformation of China's security concept began in the 1990s, and that this shift was represented by the notion of the "new security concept" proposed by China (see, for instance, [18], pp. 104-105 and [26], pp. 119-121). At the 1997 ARF Ministerial Conference, Chinese Foreign Minister Qian Qichen stated that "Multiple cross-border issues are bringing new challenges. In this situation, we should accept a new security concept. Security cannot depend on increasing armaments or military alliances. Security should rely on a new security concept that links states by mutual trust and mutual interest." [29].

The first peak of NTS mentions in Chinese official speeches was under Hu Jintao's regime (2002-2012). International NTS cooperation mechanisms during this period, such as the ARF and Shanghai Cooperation Organization, were inherited by Xi Jinping's regime. Furthermore, regarding the security domestic security motive, the

\footnotetext{
${ }^{2}$ Discourses that were used to define NTS could be classified into one of the following five patterns: (1) expressions starting with “非传统安全, 特别是”(“NTS issues especially”); (2) expressions starting with “非传统 安全, 包括” (“NTS issues including”); (3) expressions starting with “非传统安全, 如” (“NTS issues for example"); (4) expressions ending with “等非传统安全” (“et cetera”); and (5) expressions ending with “为代 表的非传统安全” (“NTS represented by").
} 


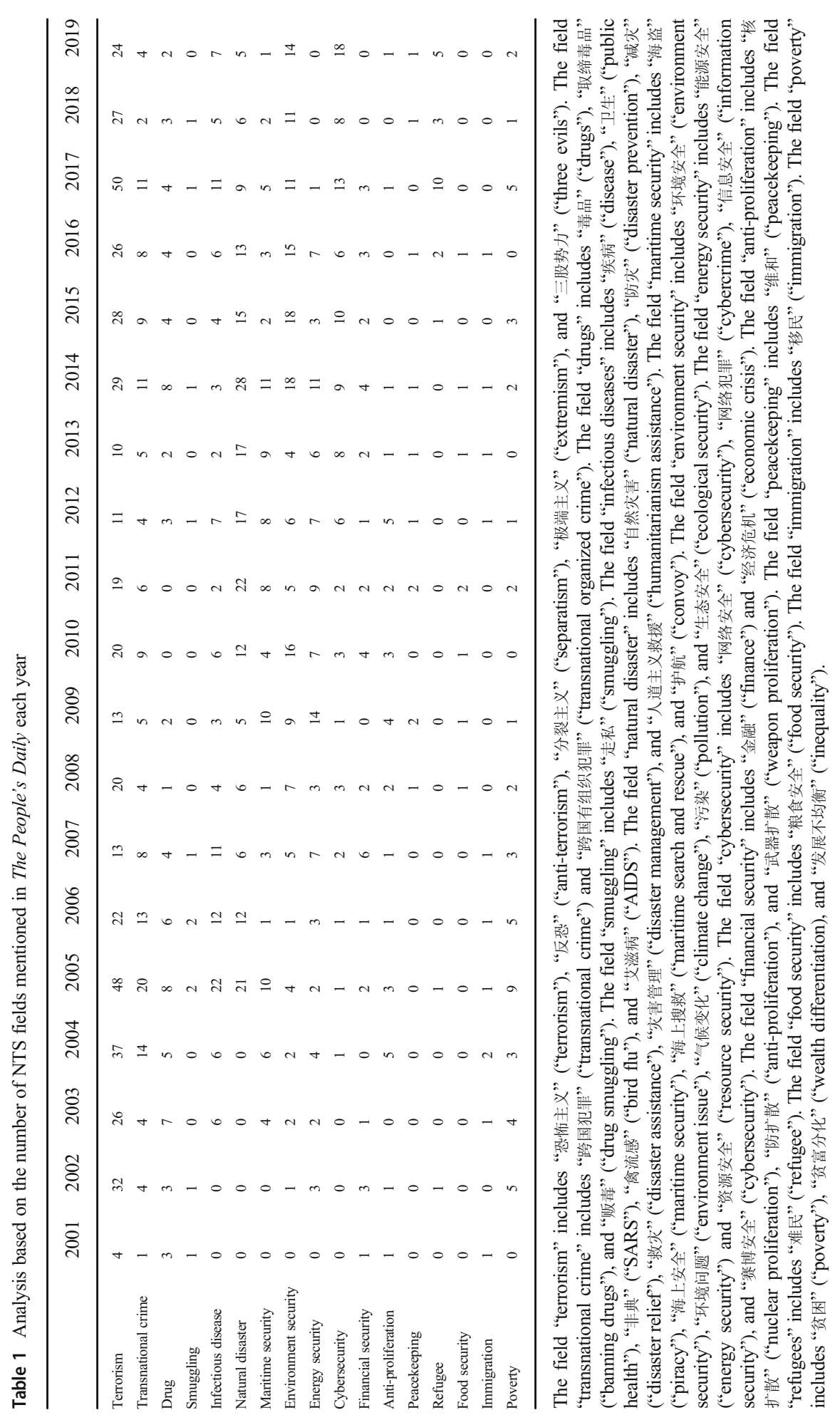


NTS policy under Xi Jinping is also consistent with that of former regimes. However, owing to a vague definition and lack of practical measures, NTS in China remained in the slogan and planning stages in this period. As shown in Table 1 and Fig. 2, during $\mathrm{Hu}$ Jintao's regime, while China rapidly promoted NTS cooperation with neighboring countries, it also continuously inserted new NTS issues into its security agenda. For example, the refugee problem was first mentioned in 2002, infectious diseases and cybersecurity in 2003, natural disasters in 2005, and peacekeeping and food security in 2008. During this period, the question of what constituted NTS issues was still controversial in Chinese policymaking. ${ }^{3}$ Furthermore, while China has frequently mentioned NTS and emphasized its significance, few legal and policy documents were promulgated by the Chinese government to support expanding NTS cooperation. Therefore, Liu Yuejin ([26], p. 127) concluded that China's NTS during this period was "some excessively idealized framework of security for the country's external security. It lacks not only internal security measures, but also lacks emphasis on realistic and feasible measures".

After Xi Jinping became the president of China in 2012, the Chinese government began to take more specific and direct actions to provide more precise guidance on its domestic and external security strategies. On April 17, 2013, China's first thematic defense White Paper, "The Diversified Use of Chinese Armed Forces," was published. This document put forward required capabilities for the Chinese army to combat NTS threats in situations such as the open seas and natural disasters. On July 1, 2015, the National Security Law of the People's Republic of China was enacted, and it clarified the significance of NTS in national security. Furthermore, in a chapter entitled "Actively Contributing to Building a Community with a Shared Future for Mankind" in its 2019 National Defense White Paper, the Chinese government stipulated that the military should promote the construction of a community of a shared future for mankind through various cooperative efforts in NTS. It is obvious that NTS has been closely related to Chinese diplomacy throughout Xi Jinping's regime. Lutgard Lams ([22]) contended that although there is no paradigmatic ideological change in the narratives, China's propaganda in this period is worth noting due to its diversified strategies and its synergy with major foreign policies such as Belt and Road Initiative. In this context, as the NTS context shifted after 2012, mentions of terrorism, environmental issues, and cybersecurity as NTS threats increased significantly as seen in Figs. 2 and 3. This paper examines these three areas as unique entities.

\section{Terrorism}

As shown in Table 1 and Fig. 2, addressing terrorist activities has always been the top priority of China's NTS. The external and domestic security environments could explain this. In the 1990 s, it was widely recognized that, because of globalization, economic fields were becoming mutually dependent. In this context, intensifying

\footnotetext{
${ }^{3}$ For instance, in 2005, Pei Yuanyin, then-director of the Policy Research Department at the Ministry of Foreign Affairs, argued that China should not expand the concept without a fixed standard. Pei also objected to defining NTS to include natural disasters, as he regarded these security issues as "traditional." See: "Ziran Zaihai Budengyu Feichuantong Anquan Weixie" [Natural Disasters $\neq$ Nontraditional Security Threats]. The People's Daily, December 9, 2005.
} 


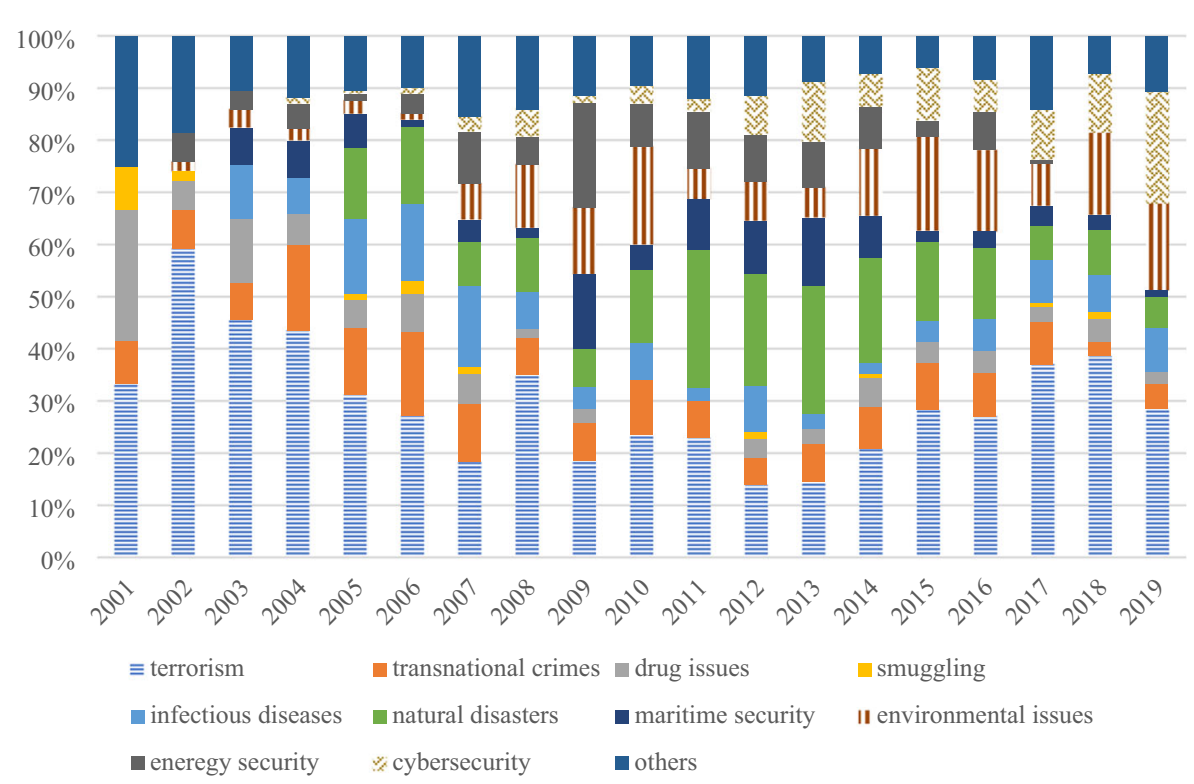

Fig. 2 The specific NTS fields mentioned in The People's Daily each year

transboundary communications also brought new challenges to both China and its neighboring countries in the form of terrorism, smuggling, and transnational crime. For decades, China has suffered from the "three evils" (terrorism, separatism, and extremism) in the Xinjiang and Tibet areas. Specifically, under Xi Jinping's regime, due to its growing geopolitical significance and security concern, China has paid increasing attention to the terrorism and extremism in Xinjiang [21, p. 413].

Due to the transnational nature of terrorism, international cooperation is indispensable in addressing it. In this context, China has actively taken initiatives and participated in multiple international cooperation mechanisms concerning terrorism. Thus,

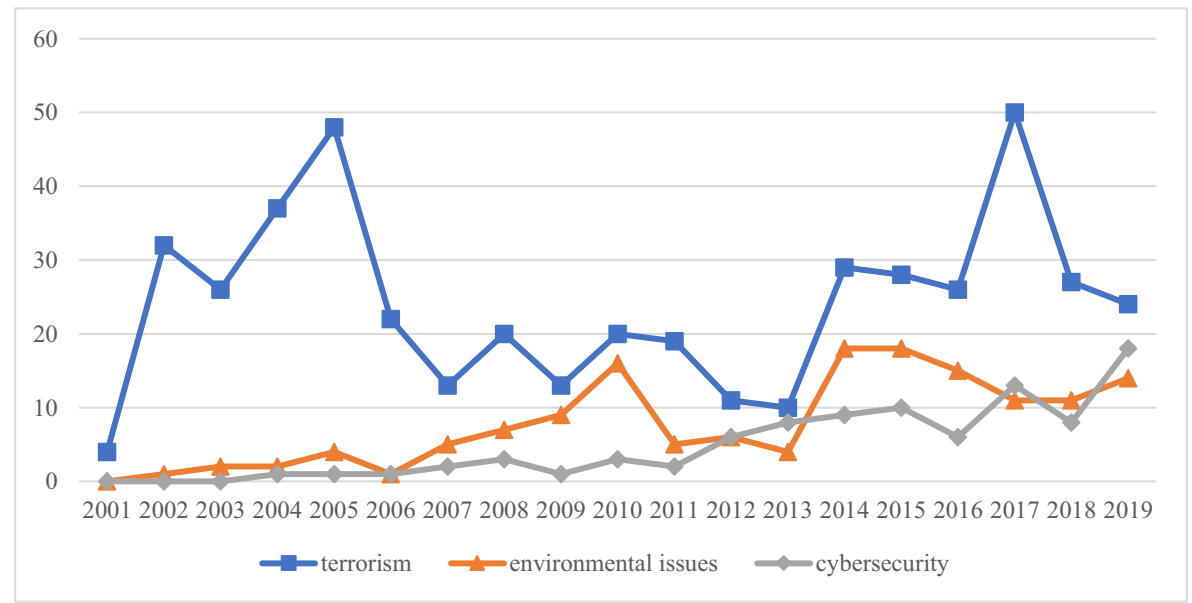

Fig. 3 The increasing mentions of terrorism, environmental issues, and cybersecurity in The People's Daily since 2013 
terrorism was securitized by China as the very first, and most important focus for its NTS agenda. In a formal meeting with US President Bill Clinton on November 14, 1994, the then Chinese president Jiang Zemin stated, "Based on the three Sino-US joint communiqués, we can jointly strengthen consultations and cooperation between the two countries in international affairs to resolve world hot issues such as the proliferation of weapons of mass destruction, environmental protection, drug enforcement, terrorism, and smuggling." [19].

On July 5, 2000, based on the "Shanghai Five" meeting on security mechanisms, China, Russia, Kazakhstan, Tajikistan, and Kyrgyzstan announced that their agreement on resolving border issues and strengthening military trust reflected a new security concept based on mutual trust, equality, and cooperation. The Shanghai Five further reaffirmed their determination to jointly fight separatism, terrorism, and extremism as they posed major threats to regional security, stability, and development as well as fighting criminal activities such as illegal arms sales, drugs, and illegal immigration [14]. This cooperation further led to the establishment of the Shanghai Cooperation Organization (SCO) in June 2001. Since its establishment, the members of the SCO have regularly conducted military exercises to promote cooperation and coordination against terrorism and other external threats. Particularly under Xi Jinping's regime, after India and Pakistan officially joined SCO as full members on 9 June 2017, it has become one of the most important nontraditional security cooperation mechanisms in Asia. In addition to cooperation in the SCO mechanism, since 2016, China has taken the initiative to build NTS cooperation mechanisms by regularly hosting events including the Great Wall International Forum on Counterterrorism and the Sharp Blade International Sniping Competition. The 2019 Great Wall International Forum attracted the participation of 30 countries. ${ }^{4}$

Terrorism is a common concern among most countries. Owing to its high applicability, terrorism is most frequently mentioned in China's official speeches at international occasions. On January 10, 2011, Chinese Minister of Defense Liang Guanglie met with Robert Gates, the US Secretary of Defense. Liang confirmed that the two countries' armies should cooperate in NTS fields such as counterterrorism, peacekeeping, naval escorts, humanitarian assistance, and disaster relief [23]. At the Fifteenth Meeting of the Council of Heads of State of the SCO Member States in Bishkek, on November 3, 2016, Prime Minister Li Keqiang stated that, "The 'three evils' are still the biggest security threat in the region" [44]. At the Thirteenth East Asian Summit held in Singapore, on November 15, 2018, Li stated that, "Currently, regional hot spots and non-traditional security threats such as terrorism are intertwining. The task of pursuing peace and promoting development is still difficult" [41].

In this research on China's mentions of terrorism in diverse situations, in addition to a domestic risk, terrorism was frequently expressed as a common threat shared by most countries. Furthermore, this emphasis indicates that, in addition to its domestic environment, China intends to promote its influence on global governance by providing cooperation opportunities.

\footnotetext{
4 "Int'l counter-terrorism forum concludes in Beijing," Xinhua, June 21, 2019. Retrieved from http://www. xinhuanet.com/english/2019-06/21/c_138162929.htm (accessed July 5, 2020).
} 


\section{Environmental Issues}

With the rapid development of China's economy, various environmental issues were added to China's political agenda. A notable sign was the significant increase in attention to environmental issues after Xi Jinping proposed the slogan "lucid waters and lush mountains are invaluable assets” (绿水青山就是金山银山). This slogan was first mentioned by $\mathrm{Xi}$ in 2005 and was widely used in official speeches by government leaders after he became the president of China in 2012. In The People's Daily, four articles mentioned the slogan in 2009, whereas 31 articles mentioned it in 2014. After $\mathrm{Xi}$ highlighted it, saying, "Building an ecological civilization is vital to sustain the Chinese nation's development. We must realize that lucid waters and lush mountains are invaluable assets and act on this understanding." in the report of the Nineteenth National People's Congress, ${ }^{5}$ this number increased to 274 mentions in 2017, 377 in 2018, and 325 in 2019.

As a result of domestic needs, China has actively participated in environmental cooperation. When meeting with John Kerry and the US Secretary of State on January 15, 2014, Xi Jinping emphasized that with regard to climate change, "It should not be done at others' requests, but on our own initiative. We have taken many measures and we will do so in the future." Xi's emphasis on this proactive position indicates China's domestic demand for addressing environmental issues. Since the US's withdrawal from the Paris Climate Agreement, China has proactively advanced the negotiations on its implementation with other parties and promoted the establishment of a global climate governance system. During the G20 summit in Osaka in June 2019, Wang Yi, the Chinese Foreign Minister; Jean Yves Le Drian, the French Foreign Minister; and António Guterres, UN Secretary-General, jointly issued a press communique on the Climate Change Conference to reaffirm their determination to promote the implementation of the Paris Climate Agreement. In July 2018, during the China-EU Summit, the China-EU Leaders' Statement on Climate Change and Clean Energy was issued. In November 2019, a Chinese government document titled "China's Policies and Actions for Addressing Climate Change 2019" was published. The document quoted Xi Jinping's instruction that "addressing climate change should not be done at others' requests, but on our own initiative. It is not only the internal need to achieve sustainable development but also the due responsibility to promote the development of the community with a shared future for mankind."7

At the same time, Chinese leaders also actively related environmental issues and international cooperation. On January 18, 2017, in Xi's speech at the UN Headquarters on "jointly building a community of a shared future for mankind," he asserted, "against the background of the continuous spread of nontraditional security threats such as terrorism, the refugee crisis, infectious diseases, and climate change, it is necessary to

\footnotetext{
5 "Full text of Xi Jinping's report at 19th CPC National Congress," Xinhua, November 3, 2017. Retrieved from http://www.xinhuanet.com/english/download/Xi_Jinping's_report_at_19th_CPC_National_Congress. pdf (accessed July 5, 2020).

6 “China and the US Jointly Addressing Climate Change," People's Daily Online, January 17, 2014. Available online, http://opinion.people.com.cn/n/2014/0217/c1003-24376678.html (accessed July 5, 2020).

7 “China's Policies and Actions for Addressing Climate Change 2019," Ministry of Ecological Environment of People's Republic of China, p. 1. Retrieved from http://english.mee.gov.cn/Resources/Reports/reports/ 201912/P020191204495763994956.pdf (accessed July 5, 2020)..
} 
strengthen international cooperation and build a community of common destiny" [12]. On March 25, 2017, in the keynote speech at the opening ceremony of the Boao Forum for the Asia Annual Conference 2017, former Vice Premier Minister Zhang Gaoli advocated, "We could strengthen cooperation in nontraditional security areas and jointly address global challenges such as terrorism, climate change, and refugee problems" [37].

When Xi Jinping became the president of China in 2012, he called for taking the initiative in addressing environmental issues, instead of passivity: it is likely that China's recognition of NTS shifted accordingly. In this period, Chinese leaders and government officials have described the environmental issues as a major issue in the process of China's development and a shared challenge by all countries. Motivated by both the domestic environment and China's pursuit of greater influence in global governance, environmental issues are playing an increasingly important role in China's foreign policy. To conclude, in the context of global climate change, NTS cooperation not only suits China's domestic situation but also provides the opportunity to enhance China's influence on the global governance system.

\section{Cybersecurity}

China introduced cybersecurity to its security agenda in the early stages of the NTS debate. In the 2002 Joint Declaration of ASEAN and China on Cooperation in the Field of Non-Traditional Security Issues, cybersecurity was already mentioned as a focus of international NTS cooperation. After 2012, in the context of the vigorous development of China's information and communications industry, various discussions of cybersecurity took place within the government. The concept of "cyberspace sovereignty" was mentioned in the National Security Law passed in July 2015. In this law, the Chinese government asserted the significance of cybersecurity and reconfirmed its irreplaceable status in national security.

Like most countries, the context of cybersecurity in China mainly involves the domestic cybersecurity situation, sovereignty, and military security considerations. On the other hand, with the increasing mentions of cybersecurity as an NTS issue after 2012, China has also actively emphasized the significance of cybersecurity in international NTS cooperation. For example, in a speech at the Asian-African Summit on April 22, 2015, Xi Jinping advocated "to jointly deal with nontraditional security issues and global challenges such as terrorism, public health, cybersecurity, and climate change, and further build a community of common destiny" [16]. At the Fourteenth East Asia Summit, held in Bangkok, Thailand, on November 4, 2019, Chinese Prime Minister Li Keqiang called for further cooperation in addressing increasing NTS challenges. Li stated, "No country can stand alone when facing prominent nontraditional security challenges such as terrorism, climate change, cybersecurity, and transnational crime. All parties must work together" [42]. Moreover, a Chinese position paper on the 70th anniversary of the establishment of the UN in September 2015 included the following statement: "Cyber-security has become a strategic issue for national sovereignty, security and development. It is necessary to develop international rules under the aegis of the UN and evolve 
a democratic and transparent multilateral mechanism for governing the Internet." 8

Like other NTS issues, China's frequent mention of cybersecurity as an NTS issue is also based on the logic that addressing these problems is of mutual benefit to China and other countries. In its speeches, China described cybersecurity as a major issue that is vital to national security, while also emphasizing the interests shared by China and other countries in this field. On the one hand, China can solve its domestic problems through such international cooperation; on the other hand, promoting such cooperation can also further China's goal of gaining influence within the global governance system.

Furthermore, because of its connection to national sovereignty and military security, other countries have been attentive and vigilant when it comes to China's information and communications industry. In 2018, the US-imposed sanctions against the Chinese telecom giant ZTE and the Meng Wanzhou incident marked an irreconcilable rift between China and its rival countries in the area of cybersecurity. In this context, China advocating for international morality such as mutual trust and mutual benefits in cybersecurity cooperation would not only increase the potential for international cooperation, but also justify the country's foreign policy in the cybersecurity field. As Yavuz Akdag [1 , p. 225] pointed out, although cyberwar between China and the US currently seems unlikely, China will pursue switching the status quo in cyberspace in its favor, especially if it remains dissatisfied with the current cyber order. Therefore, it could be said that China's increasing emphasis on cybersecurity also reflects its motivation to actively promote innovation in the global governance system.

\section{Discussion}

To conclude, the logic behind mentions of China's major NTS concerns of terrorism, environmental issues, and cybersecurity in official speeches since 2012 serves China's purpose to actively play a greater role in the global governance system. Under $\mathrm{Xi}$ Jinping's regime, the logic in common behind China's NTS coincides with its aim to lead international efforts to enhance global governance and explore new models of cooperation. In a government working report at the Nineteenth National Congress held on October 27, 2017, Xi stated that "We must adhere to promoting the construction of a community of a shared future for mankind. We must pursue an open strategy based on mutual benefit and establish a common, comprehensive, cooperative, and sustainable new security concept. We must stick to the role of the builder of world peace, the contributor to global development, and the maintainer of the international order" [45].

Under China's NTS international cooperation under Xi's regime, the role of the UN and other regional dialogue mechanisms, such as the Asian-African Summit and ARF, were frequently emphasized by Chinese government leaders. At the same time, China also showed its cooperative stance by promoting existing NTS missions such as UN peacekeeping operations and the Paris Climate Agreement. As analyzed in this paper, domestic security issues are also an important concern for China's active participation

\footnotetext{
8 "China's Position Paper on the 70th Anniversary of the United Nations," The State Council of the People's Republic of China. Available online, http://english.www.gov.cn/archive/publications/2015/09/22/content_ 281475195602584.htm (accessed July 5, 2020).
} 
in the global governance system. It can be said that in the field of NTS, including terrorism, environmental issues and cybersecurity, China is the main beneficiary of the existing global governance system. Therefore, although scholars have pointed out that China will probably not contribute to global governance mechanisms that it has not created [20], in the areas of NTS, it is likely that it will see itself as a stakeholder in the existing mechanisms of international cooperation and global governance. In an interview in the Wall Street Journal, Xi Jinping stated that, "Adjusting and reforming the global governance system and mechanism is not about dismantling the existing system and creating a new one to replace it. Rather, it aims to improve the global governance system in an innovative way, so that it can better suit changes in the international environment and more fairly reflect the wills and interests of most countries, especially emerging countries and developing countries." Xi's stance can be interpreted as conveying China's demands for innovation in the global governance system. However, at the same time, China's active participation in the current global governance system also indicates the possibility that China is not necessarily a challenger of the existing international order, as long as its demands are being fulfilled.

Moreover, it is worth noting that in NTS fields such as cybersecurity, China has also drawn much careful observation and criticism. To dispel such negative impressions, within these NTS fields, China has come to see it as an urgent goal to expand its influence over international discourse. China's propaganda emphasizing the importance of international cooperation in NTS areas can also be seen as a measure to gain such influence. On July 16, 2014 in a speech at the National Congress of Brazil, Xi Jinping mentioned the significance of striving for greater influence in international discourse, "We should advocate the concept of common, comprehensive, cooperative and sustainable security, and jointly respond to the increasing nontraditional security threats. We should strengthen coordination and cooperation within international and multilateral mechanisms, actively participate in global governance, and strive for more institutional power and discourse influence for developing countries" [15]. Besides the emphasis on international morality, the effort to extend its international influence through participation in global governance and provision of public goods has also led to further discussion in China. Chen Xulong, Director of the Department for International and Strategic Studies at the China Institute of International Studies, stated, "China must combine the promotion of the rule of law in the global governance system and the promotion of China's discourse influence in the global governance system" [4]. On April 2, 2020, in an article in The People's Daily entitled "Improving the Power of Discourse in Telling Chinese Stories," Fu Ying, former Vice Minister of the Ministry of Foreign Affairs, advocated the "telling [of] Chinese stories wisely and appropriately" and "enhancing the international power of discourse" [43]. These views also indicate China's demand for international innovation on its initiatives.

Finally, regarding the securitizing actors and audience, articles from The People's Daily show that there are diverse functional actors promoting the process of securitization. For example, the military actively promotes the securitization of piracy, naval escorts, and disaster relief, all of which relate to their mission. In addition, commercial

\footnotetext{
9 "Interview with Chinese President Xi Jinping; China's President Offers Written Answers to Questions from The Wall Street Journal," The Wall Street Journal, September 22, 2015. https://www.wsj.com/articles/fulltranscript-interview-with-chinese-president-xi-jinping-1442894700 (accessed July 5, 2020).
} 
interests promote the securitization of specific issues that might benefit them. ${ }^{10} \mathrm{How}$ ever, given the guiding position of The People's Daily in China's propaganda, most of those securitization processes are very likely in step with the will and guidance of the Chinese central government. Moreover, after Xi Jinping became Chinese president and through the anti-corruption struggle and a series of personnel appointments, it is considered that the domestic opposition forces were generally suppressed, and that political power was significantly centralized [2, pp., 5-8]. Therefore, it can be concluded that the securitization process is primarily conducted by the Chinese government officials with Xi Jinping at the core. In other words, the Chinese central government guided by Xi Jinping's will is the main actor for the securitization process of NTS issues. In this context, the main purpose of securitizing NTS issues can be seen as (1) legitimating further policymaking and thus, reducing resistance to policy implementation; and (2) enhancing the possibility of future international cooperation. Accordingly, the audience of this securitizing process are Chinese citizens and other government officials, and foreign governments and foreign opinions. In the context of China's pursuit of reforms in the global governance system, it is especially noteworthy that China has securitized NTS issues in its propaganda against other countries.

\section{Conclusion}

Having inherited the characteristics of the "new security concept" first raised in the 1990s, and as most NTS fields were initially introduced in the early 2000s, China's NTS cooperation since 2012 has been more reminiscent of an already existing idea being presented as a new one, rather than something fresh and original. As China has increasingly pursued influence in the global governance system under Xi Jinping's regime, the role of NTS is indispensable in China's foreign policy. Thus, China's securitization of NTS issues has been guided by more specific and assertive policies and strategies, such as NTS cooperative mechanisms and government documents. In this process of the securitization of NTS issues, the Chinese government described NTS issues, such as terrorism, environmental issues, and cybersecurity, as the key to China's own survival and emphasized the common interests shared by China and other countries in this field. To conclude, after 2012, China's emphasis on NTS has been a phenomenon related to its pursuit of innovating global governance systems on China's initiative. Based on a body of legislation and a clear international strategy, the NTS has played an increasingly important role in China's foreign policy.

Under Xi Jinping's regime, China has attempted to explore a new model of global governance by, for instance, founding the Asian Infrastructure Investment Bank. However, China is simultaneously manifesting its intention to contribute to the existing global governance mechanisms. Such contributions indicate that China can benefit from the existing mechanisms. Especially within the domestic security environment, China cannot address existing NTS challenges such as terrorism and environmental

\footnotetext{
${ }^{10}$ For example, Zhou Hongyi, CEO of the Chinese Internet giant 360, published an article in The People's Daily, emphasizing the importance of cybersecurity. See: "Woguo wangluo anquan xutisheng zhengti fangyu nengli (China's cybersecurity needs to improve its overall defense capabilities)," The People's Daily, December 29, 2017.
} 
issues without these global governance systems. This explains China's strong intention to promote NTS international cooperation under the existing framework. Moreover, considering the increasing debates over whether China will be a free rider or challenger in global governance mechanisms, this cooperative stance can be seen indispensable in China's attempt to dispel those concerns.

However, although China still shows a strong willingness to cooperate based on the existing NTS global governance system, it has been recognized that the existing system requires reforms to achieve more just and equitable burden-sharing ([3], p. 193). Therefore, China's appeal to such systematic innovation in NTS cooperation should not be ignored. In speeches related to NTS, China has demonstrated its motivation to compete for a greater influence on discourse in international affairs. In the context of the US withdrawal from the global strategic stage, China's promotion of the construction of a "community of a shared future for mankind" and the Belt and Road Initiative play a role in global governance, and supply public goods that can also be seen as a means for China to increase its influence. Since the beginning of 2020, the global COVID-19 pandemic has led to China experiencing massive international criticism. It is thus predictable that China will accelerate the process of attempting to regain power in global governance and international discourse in the future.

\section{References}

1. Akdag, Yavuz. 2019. The likelihood of Cyberwar between the United States and China: A neorealism and power transition theory perspective. Journal of Chinese Political Science 24: 225-247. https://doi. org/10.1007/s11366-018-9565-4.

2. Amako, Satoshi. 2018. Domestic and foreign policies during xi Jinping's second term and future prospects for China [第二期習近平政権の内外政策と今後の展望]. Issues \& Studies [問題と研究: アジア太平 洋研究専門誌] 47 (3): 1-33.

3. Boutellis, Arthur. 2020. Rethinking UN peacekeeping burden-sharing in a time of global disorder. Fudan Journal of Humanities and Social Science 13: 193-209. https://doi.org/10.1007/s40647-019-00274-2.

4. "Buju fengyu yongxiangqiang (Move Forward Bravely)." The People's Daily, April 15, 2018.

5. Buzan, Barry. 1983. People, states and fear: The national security problem in international relations. Brighton: Wheatsheaf.

6. Buzan, Barry, Ole Wæver, De Wilde, and Jaap. 1998. Security: A new framework for analysis. London: Lynne Rienner.

7. Caballero-Anthony, Mely, ed. 2016. An introduction to non-traditional security studies: A transnational approach. London: Sage Publications.

8. Cai, Kevin G. 2020. Constructing an analytical framework for explaining Chinese foreign policy. Chinese Political Science Review 5: 355-373. https://doi.org/10.1007/s41111-020-00150-5.

9. In Chan, Seng, and Weiqing Song. 2020. Telling the China story well: A discursive approach to the analysis of Chinese foreign policy in the "belt and road" initiative. Chinese Political Science Review 5: 417-437. https://doi.org/10.1007/s41111-020-00146-1.

10. Ding, Jun, and Hongjin Cheng. 2017. China's proposition to build a community of shared future for mankind and the Middle East governance. Asian Journal of Middle Eastern and Islamic Studies 11 (4): $1-14$.

11. Ghiselli, Andrea. 2018. Diplomatic opportunities and rising threats: The expanding role of non-traditional security in Chinese foreign and security policy. Journal of Contemporary China 27 (112): 611-625.

12. "Gongtong goujian renleimingyun gongtongti" [Jointly Build a Community of a Shared Future for Mankind]. The People's Daily, January 20, 2017.

13. Hansen, Lene. 2011. The politics of securitization and the Muhammad cartoon crisis: A post-Structuralist perspective. Security Dialogue 42 (4-5): 357-369.

14. "Hasakesitan gongheguo zhonghua renmin gongheguo jierjisigongheguo eluosi lianbang he tajikesitan gongheguo yuanshou dushangbie shengming" [Dushanbe Declaration of Heads of State of the Republic 
of Kazakhstan, the People's Republic of China, the Kyrgyz Republic, the Russian Federation and the Republic of Tajikistan]. The People's Daily, July 6, 2000.

15. "Hongyang chuantong youhao gongpu hezuo xinpian-zai baxi guohui de yanjiang" [Promoting Traditional Friendship and Jointly Writing a New Chapter of Cooperation-Speech at the Brazilian Congress]. The People's Daily, July 18, 2014.

16. "Hongyang wanlong jingshen tuijin hezuo gongying" [Carry Forward the Bandung Spirit and Promote Mutual Benefit Cooperation]. The People's Daily, April 23, 2015.

17. Huysmans, Jef. 1998. Revisiting Copenhagen: Or, on the creative development of a security studies agenda in Europe. European Journal of International Relations 4: 479-505.

18. Iida, Masashi. 2003. "China's security cooperation for Southeast Asia: Focusing on ARF” [中国の東 南アジアに対する安保協力—ARFへの対応を中心に]. Bulletin of National Defense Research Institute [防衛 研究所紀要] 6 (1): 95-107.

19. "Jiangzhuxi zaiyajiada tong baguo lingdaoren huiwu" [President Jiang Met with Leaders of Eight Countries in Jakarta]. The People's Daily, November 15, 1994.

20. Joseph S, Nye Jr. 2017. “The Kindleberger Trap.” Project Syndicate, January 9, 2017. https://www. project-syndicate.org/commentary/trump-china-kindleberger-trap-by-joseph-s\%2D\%2Dnye-2017-01? barrier=accesspaylog (accessed July 5, 2020).

21. Klimeš, Ondřej. 2018. Advancing "ethnic Unity" and "De-Extremization": Ideational governance in Xinjiang under "new circumstances" (2012-2017). Journal of Chinese Political Science 23: 413-436. https://doi.org/10.1007/s11366-018-9537-8.

22. Lams, Lutgard. 2018. Examining strategic narratives in Chinese official discourse under xi Jinping. Journal of Chinese Political Science 23: 387-411. https://doi.org/10.1007/s11366-018-9529-8.

23. "Liangguanglie yu meiguo guofangbuzhang gaici huitan" [Liang Guanglie Talks with US Defense Secretary Gates]. The People's Daily, January 11, 2011.

24. Lim, Tai Wei. 2017. Trans-Pacific partnership and political motivations: Interpretive work based on analyses of the Chinese state media. DLSU Business and Economics Review 27 (1): 201-209.

25. Liu, Qingyao. 2018. From climate change to climate security: A study on the state's securitization behavior [从气候变化到气候安全:国家的安全化行为研究]. Journal of International Security Studies [国际安全 研究] 6: 130-151.

26. Liu, Yuejin. 2014. China's official concept of non-traditional security: Historical evolution and logical composition [中国官方非传统安全观的历史演进与逻辑构成]. Journal of International Security Studies [国际 安全研究] 2: 117-129.

27. Masuda, Masayuki. 2009. The logic and development of China's security policy-foreign policy and military on nontraditional security [中国の安全保障政策の論理と展開一非伝統的安全保障をめぐる外交と軍 事]. International Affairs [国際問題] 581: 42-51.

28. Nie, Wenjuan. 2016. Xi Jinping's foreign policy dilemma: One belt, one road or the South China Sea? Contemporary Southeast Asia 38 (3): 422-444.

29. “Qian Qichen Jiu Yatai Jushi Chanshu Woguandian” [Qian Qichen Stated China's Views and Positions on the Asia-Pacific Situation]. The People's Daily, July 28, 1997.

30. Reeves, Jeffrey. 2014. A search for causality: China's non-traditional security and state weakness. European Journal of East Asian Studies 13: 93-116.

31. Shi, Bin. 2014. Human security vs national security: Ethical arguments and policy choices [人的安全”与国 家安全——国际政治视角的伦理论辩与政策选择]. World Economics and Politics [世界经济与政治] 2: 85-110.

32. Swaine, Michael D. 2011. China's assertive behavior part I: "Core interests". China Leadership Monitor 34: 1-25.

33. Vuori, Juha A. 2008. Illocutionary logic and strands of securitization: Applying the theory of securitization to the study of non-democratic political orders. European Journal of International Relations 14 (1): 65-99.

34. Wæver, Ole. 1995. Securitization and desecuritization. In On security, ed. R. Lipschutz. New York: Columbia University Press.

35. Wæver, Ole. 2011. Politics, security, theory. Security Dialogue 42 (4-5): 465-480.

36. Wibisono, Ali Abdullah. 2017. ASEAN-China non-traditional security cooperation and the inescapability of the politics of security. Jurnal Global dan Strategis 11 (1): 39-54.

37. "Xieshou tuijin jingji quanqiuhua gongtong kaichuang yazhou he shijie meihao weilai" [Join Hands to Promote Economic Globalization and Jointly Create a Better Future for Asia and the World]. The People's Daily, March 26, 2017.

38. Cho, Young Chul, and Hwang, Yih-Jye. 2020. Mainstream IR Theoretical Perspectives and Rising China Vis-À-Vis the West: The Logic of Conquest, Conversion and Socialisation. Journal of Chinese Political Science 25: 175-198. 10.1007\%2Fs11366-019-09620-3. 
39. Yu, Xiaofeng, and Jiangli Wang. 2006. Maintenance of non-traditional security: Boundary, context and paradigm [非传统安全维护的“边界”、“语境”与“范式”]. World Economics and Politics [世界经济与政治] 11: 55-61.

40. Yu, Xiaofeng, and Guiping Xie. 2015. "Selectivity" reconstruction: Extending the concept of securitization [“选择性”再建构:安全化理论的新拓展]. World Economics and Politics [世界经济与政治] 9: 104-121.

41. "Zai dishisanjie dongyafenghui shangde jianghua" [Speech at the 13th East Asian Summit]. The People's Daily, November 16, 2018.

42. "Zai dishisijie dongyafenghui shangde jianghua" [Speech at the 14th East Asia Summit]. The People's Daily, November 6, 2019.

43. "Zai jianghao zhongguo gushi Zhong tisheng huayuquan" [Promoting the Discourse Influence in Telling Chinese Stories]. The People's Daily, April 2, 2020.

44. "Zai shanghai hezuozuzhi chengyuanguo shounao lishihui dishiwuci huiyi shangde jianghua" [Speech at the 15th Meeting of the Council of Heads of State of the Shanghai Cooperation Organization Member States]. The People's Daily, November 4, 2016.

45. "Zai zhongguo gongchandang dishijiuci quanguodaibiaodahui shangde baogao" [Report at the 19th National Congress of the Communist Party of China]. The People's Daily, October 28, 2017.

46. Zhao, Xiaochun. 2018. In pursuit of a community of shared future: China's global activism in perspective. China Quarterly of International Strategic Studies 9: 23-37.

47. Zhu, Ning. 2003. Securitization and desecuritization: Security study of Copenhagen school [安全与非安全 化——哥本哈根学派安全研究]. World Economics and Politics [世界经济与政治] 10: 21-26.

Liu Hongyi is a doctoral program student in Graduate School of Social Science, Waseda University, Japan. LIU Hongyi's research is mainly focused on China's non-traditional security policy and nontraditional security international cooperation in East Asia. 